\title{
Validation of Martilli's urban boundary layer scheme with measurements from two mid-latitude European cities
}

\author{
R. Hamdi ${ }^{1}$ and G. Schayes ${ }^{2}$ \\ ${ }^{1}$ Royal Meteorological Institute, Avenue Circulaire, 3, 1180 Brussels, Belgium \\ ${ }^{2}$ Institut d'Astronomie et de Géophysique, University of Louvain, Belgium \\ Received: 8 April 2005 - Published in Atmos. Chem. Phys. Discuss.: 1 July 2005 \\ Revised: 21 August 2007 - Accepted: 21 August 2007 - Published: 31 August 2007
}

\begin{abstract}
Martilli's urban parameterization scheme is improved and implemented in a mesoscale model in order to take into account the typical effects of a real city on the air temperature near the ground and on the surface exchange fluxes. The mesoscale model is run on a single column using atmospheric data and radiation recorded above roof level as forcing. Here, the authors validate Martilli's urban boundary layer scheme using measurements from two mid-latitude European cities: Basel, Switzerland and Marseilles, France. For Basel, the model performance is evaluated with observations of canyon temperature, surface radiation, and energy balance fluxes obtained during the Basel urban boundary layer experiment (BUBBLE). The results show that the urban parameterization scheme represents correctly most of the behavior of the fluxes typical of the city center of Basel, including the large heat uptake by the urban fabric and the positive sensible heat flux at night. For Marseilles, the model performance is evaluated with observations of surface temperature, canyon temperature, surface radiation, and energy balance fluxes collected during the field experiments to constrain models of atmospheric pollution and transport of emissions (ESCOMPTE) and its urban boundary layer (UBL) campaign. At both urban sites, vegetation cover is less than $20 \%$, therefore, particular attention was directed to the ability of Martilli's urban boundary layer scheme to reproduce the observations for the Marseilles city center, where the urban parameters and the synoptic forcing are totally different from Basel. Evaluation of the model with wall, road, and roof surface temperatures gave good results. The model correctly simulates the net radiation, canyon temperature, and the partitioning between the turbulent and storage heat fluxes.
\end{abstract}

Correspondence to: R. Hamdi

(rafiq.hamdi@oma.be)

\section{Introduction}

Numerous investigations have shown that buildings and urban land use significantly modify the micro and mesoscale flow fields (Bornstein, 1987). Since mesoscale models do not have the spatial resolution to simulate the fluid dynamic and thermodynamic in and around urban structures, an urban canopy parameterization is used to represent the drag, heating, radiation attenuation, and enhanced turbulent mixing produced by the sub-grid scale urban elements.

The classical approach for taking into account the presence of an urban area in mesoscale models uses Monin-Obukhov Similarity Theory (MOST), like for rural area, but with a larger roughness length $Z_{0}$ and different soil thermal characteristics. Field measurements (e.g. Rotach, 1993a, b) have shown that this approach is not able to reproduce the vertical structure of turbulence field in the so-called urban roughness sublayer. In response to the numerous limitations of the simple urbanization approaches, recent efforts have focused on incorporation of sophisticated techniques to parameterize urban effects on the thermodynamic and momentum fields in mesoscale and buildings-scale numerical models. Sievers (1990) modified the turbulence length scale and exchange coefficient based on wall-area density. For models with higherorder turbulence closure schemes, an additional source term is added to the TKE equation (Maruyama, 1999; Urano et al., 1999). Concerning thermal effects, recent models move some or all anthropogenic heat from the surface energy budget to the prognostic atmospheric thermodynamic equation (Ca et al., 1999; Taha, 1999). This is done with an appropriately high vertical resolution. The surface energy balance can also be modified by taking into account the shadowing and radiative trapping effects of buildings (Masson, 2000). Brown (2000) gives an exhaustive picture of urban parameterization attempts.

In this study, we use the parameterization of Martilli et al. (2002) which combines the thermal and dynamical effects

Published by Copernicus Publications on behalf of the European Geosciences Union. 
Table 1. Description of the micro-meteorological towers used for the two urban sites.

\begin{tabular}{|c|c|c|}
\hline Site & U1 (Basel) & CAA (Marseilles) \\
\hline Location & $47^{\circ} 33^{\prime} \mathrm{N} 7^{\circ} 35^{\prime} \mathrm{E}$ & $43^{\circ} 17^{\prime} \mathrm{N} 5^{\circ} 22^{\prime} \mathrm{E}$ \\
\hline Height a.s.l. & $255 \mathrm{~m}$ & $70 \mathrm{~m}$ \\
\hline Height of tower & $32 \mathrm{~m}$ & 34.6 and $43.9 \mathrm{~m}$ \\
\hline Building height & $14.6 \mathrm{~m}$ & $15.6 \mathrm{~m}$ \\
\hline Height/Width $(\mathrm{H} / \mathrm{W})^{\mathrm{a}}$ & 1.30 & 1.63 \\
\hline Street direction ${ }^{b}$ & $67^{\circ}$ and $157^{\circ}$ & $84^{\circ}$ and $174^{\circ}$ \\
\hline Vegetation $^{c}$ & $\lambda_{V}=16 \%$ & $\lambda_{V}=14 \%$ \\
\hline Ultrasonic Anemometers & F 31.7 m E 22.4 m D 17.9 m C 14.7 m B 11.3 m A 3.6 m & 37.9 or $43.9 \mathrm{~m}$ \\
\hline Net radiation & $31.5 \mathrm{~m}$ & $37.9 \mathrm{~m}$ \\
\hline Latent and Sensible heat & $31.7 \mathrm{~m}$ & $37.9 \mathrm{~m}$ \\
\hline
\end{tabular}

${ }^{\mathrm{a}} \mathrm{H}$ height of the building and $\mathrm{W}$ width of the street canyon.

$\mathrm{b}$ The orientations of the street are deduced from a city map. This input is crucial for the incoming solar radiation on the walls and, hence, for the energy balance.

${ }^{c}$ Vegetated fraction, calculated for a circle of $250 \mathrm{~m}$ around the sites by air photo analysis. $\lambda_{V}$ describes the plan area of vegetated surfaces per total plan area.

of the urban canopy. This urban module represents the city as a combination of three urban surfaces (street, roof, and wall), characterized by the size of the street canyon and the building and is thus able to take into account the sink of momentum over the entire height of the building, as well as the shadowing and the radiation trapping effects, which are commonly neglected. Martilli's urban scheme is one of the most complete parameterization of urban effects, no other urban parameterization, except Masson (2000), explicitly considers the effects of buildings, roads, and other artificial materials on the urban surface energy budget. However, Martilli's urban scheme did not include vegetation in its original version, and in the literature a lot of numerical simulations and field measurements indicate that increasing vegetation cover in urban area can be effective in reducing the surface and air temperature near the ground (Taha, 1997). Thus, in order to take into account the vegetation effect on urban canopy, we divide the urban grid cell into a non-urban fraction (vegetated fraction $\left.\lambda_{V}\right)$ and a urban fraction $\left(1-\lambda_{V}\right)$, and then further subdivide the urban canopy fraction into street, wall, and roof according to Martilli's scheme. This method was used also by Brown and Williams (1998). This new version is implemented in a mesoscale model (Schayes et al., 1996) and in this study the model is run on a 1-D-column. Therefore, the goal of the present contribution is to validate this urbanized version of the mesoscale model using directly measured canyon air temperature, surface temperature, and surface energy balance fluxes for two homogeneous urban sites: one is located in a heavily built-up part of Basel, Switzerland, the other is located in the dense city center of Marseilles, France. At both sites vegetation cover is less than $20 \%$ of the local plan area but the sites are otherwise very different in terms of the urban parameters and the synoptic forcing.

\section{Observations}

Here we present a brief overview of the observation methods used to gather data appropriate to the evaluation of the urbanized version of our mesoscale model. More complete details are available in Rotach et al. (2005) and Mestayer et al. (2005) for Basel and Marseilles, respectively.

\subsection{Measurements sites}

\subsubsection{Basel, Switzerland}

As a part of the BUBBLE (Basel urban boundary layer experiment) measurements in 2001-2002 in the city of Basel, Switzerland, a micro-meteorological tower was operated in dense urban areas for 9 months: Basel-Sperrstrasse (U1) (Fig. 1a). This site is located in a heavily built-up part of the city ("European urban", dense urban, mainly residential 3 to 4 storey buildings in blocks, flat commercial and light industrial buildings in the backyards). The measurements set up consists of a tower inside a street canyon reaching up to a little more than two times the building height, where six ultrasonic anemometer-thermometers and full radiation component measurements are installed (Table 1).

\subsubsection{Marseilles, France}

Coupled to the ESCOMPTE (the field experiments to constrain models of atmospheric pollution and transport of emissions) campaign, the UBL (urban boundary layer) program (Mestayer et al., 2005) documented radiative surface temperatures, surface energy balance fluxes, and the 4-D structure of the boundary layer of the city of Marseilles. ESCOMPTEUBL took place during the summer of 2001, from 4 June to 16 July. The site is located in the down-town core 
Table 2. The average daytime/nighttime partitioning of all observed energy balance components for U1: 17, 18, 23, 26 and 30 June 2002 and CAA: between 18 and 30 June 2001. $\mathrm{S} \downarrow, \mathrm{S} \uparrow, \mathrm{L} \uparrow$, and $\mathrm{L} \downarrow$ represent the observed incoming and outgoing solar and longwave radiation, recorded at the top of the tower for U1 and CAA. Daytime values (D) are averaged from 08:00 to 16:00 UTC, nocturnal value (N) from 22:00 to 03:00 UTC. Unit is $\mathrm{W} \mathrm{m}^{-2}$.

\begin{tabular}{llllllllllllllllll}
\hline & $\mathrm{S} \downarrow$ & & $\mathrm{S} \uparrow$ & $\mathrm{L} \downarrow$ & & $\mathrm{L} \uparrow$ & & $\mathrm{Q}^{*}$ & & $\mathrm{Q}_{H} / \mathrm{Q}^{*}$ & & $\mathrm{Q}_{S} / \mathrm{Q}^{*}$ & \multicolumn{3}{c}{$\mathrm{Q}_{E} / \mathrm{Q}^{*}$} & \\
\hline & $\mathrm{D}$ & $\mathrm{N}$ & $\mathrm{D}$ & $\mathrm{N}$ & $\mathrm{D}$ & $\mathrm{N}$ & $\mathrm{D}$ & $\mathrm{N}$ & $\mathrm{D}$ & $\mathrm{N}$ & $\mathrm{D}$ & $\mathrm{N}$ & $\mathrm{D}$ & $\mathrm{N}$ & $\mathrm{D}$ & $\mathrm{N}$ \\
\hline $\mathrm{CAA}$ & 742 & 0 & 124 & 3 & 340 & 320 & 473 & 400 & 486 & -86 & 0.60 & -0.28 & 0.32 & 1.3 & 0.09 & -0.11 \\
$\mathrm{U} 1$ & 741 & 0 & 72 & 3 & 360 & 340 & 521 & 420 & 510 & -82 & 0.48 & -0.21 & 0.32 & 1.3 & 0.16 & -0.19 \\
\hline
\end{tabular}

of Marseilles centered on the Cour d'Appel Administrative (CAA) (Fig. 1b). The site is a dense commercial and residential area with 4-6 story buildings. A pneumatic tower was installed on the roof of the CAA at $43.9 \mathrm{~m}$ above ground level (AGL) under light wind conditions and at $37.9 \mathrm{~m}$ under strong wind conditions (base of the tower was $20.7 \mathrm{~m}$ above ground level) (Table 1).

\subsection{Instrumentation}

At both sites, the highest instruments were mounted high enough above the surface to ensure that the measurements are representative of the local scale. The data collected at both sites included temperature, humidity, wind speed, turbulent kinetic energy, pressure, upward and downward global short- and long-wave radiation, and the surface energy balance fluxes. Sensible heat flux density $\mathrm{Q}_{H}$ and latent heat flux $\mathrm{Q}_{E}$ are directly derived from eddy correlation measurements using three-dimensional ultrasonic anemometerthermometers combined with humidity fluctuation measurements, while the heat storage flux $\Delta \mathbf{Q}_{S}$ was determined as the residual term. In Marseilles city, additional data used in the analyses includes the following:

1. External surface temperatures for roads, roofs, and walls for street around CAA (Lemonsu et al., 2004).

2. A network of 20 temperature and relative humidity sensors located in the middle of street (Pigeon et al., 2002). Instruments were mounted approximately $6 \mathrm{~m}$ a.g.l., and were located as far as possible away from walls, to minimize the effects of shaded or sunlit surfaces. Five of these instruments were located in the city core, close to the CAA's tower (Lemonsu et al., 2004).

For each urban site a rural reference station was selected.

\subsection{Comparison between U1 and CAA}

Table 2 summarizes the average daytime/nighttime partitioning of all observed energy balance components for selected clear sky days: 17, 18, 23, 26, and 30 June 2002 for U1, and all days between 18 and 30 June 2001 for CAA. The ratios $\mathrm{Q}_{H} / \mathrm{Q}^{*}, \Delta \mathrm{Q}_{S} / \mathrm{Q}^{*}$, and $\mathrm{Q}_{E} / \mathrm{Q}^{*}$ are useful parameters for the detection of diurnal trends in the partitioning of the net radiation $\mathrm{Q}^{*}$ into $\mathrm{Q}_{H}, \Delta \mathrm{Q}_{S}$, and $\mathrm{Q}_{E}$ and for comparing situations with different magnitudes of $\mathrm{Q}^{*}$ forcing. $\mathrm{S} \downarrow, \mathrm{S} \uparrow, \mathrm{L} \uparrow$, and $\mathrm{L} \downarrow$ represent the observed incoming and outgoing solar and longwave radiation, recorded at the top of the tower for $\mathrm{U} 1$ and $\mathrm{CAA}$ in $\mathrm{W} \mathrm{m}^{-2}$. Daytime values are averaged from 08:00 to 16:00 UTC, nocturnal values from 22:00 to 03:00 UTC.

During daytime, $\Delta \mathrm{Q}_{\mathrm{CAA}-\mathrm{U} 1}^{*}=-24 \mathrm{~W} \mathrm{~m}^{-2}$, i.e. $\mathrm{U} 1$ gains more energy compared to CAA, an effect mainly controlled by the low urban albedo in U1. In fact, while the observed outgoing solar radiation $\mathrm{S} \uparrow$ for CAA is typically around $124 \mathrm{~W} \mathrm{~m}^{-2}$ it is only $72 \mathrm{~W} \mathrm{~m}^{-2}$ for U1. Even if the trapping of shortwave radiation is very strong in CAA, canyon albedo around 0.04 (Lemonsu et al., 2004), it seems that the effective albedo in CAA is influenced by the thermal properties of building and road material rather than by the trapping effect. For U1, L $\uparrow$ values are higher in magnitude than $\mathrm{L} \uparrow$ ones measured over CAA most of the time. This implies a higher urban radiation surface temperature and/or a different emissivity. We note that Marseilles is considerably more to the south than Basel, it has a much more Mediterranean climate, and it is characterized by the presence of strong winds. Under sea breeze conditions, a cold advection from the sea takes place and intensifies the temperature gradient between the ground and the atmosphere. As a consequence, the partitioning between $\mathrm{Q}_{H}$ and $\Delta \mathrm{Q}_{S}$ favors the turbulent sensible heat flux $\mathrm{Q}_{H} / \mathrm{Q}^{*}=0.6$. The increased $\mathrm{Q}_{H} / \mathrm{Q}^{*}$ at $\mathrm{CAA}$ is counterbalanced by reduced $\mathrm{Q}_{E} / \mathrm{Q}^{*}=0.09$. Daytime Bowen ratio $\beta=\mathrm{Q}_{H} / \mathrm{Q}_{E}$ values are typically twice as large in CAA as in $\mathrm{U} 1$, even if the fraction of vegetation is approximately the same for the two urban sites. In fact, the Bowen ratio of urban surfaces may depend on various factors like climatic setting of the city, precipitation, phenology and the difference between rural and urban discharge coefficients. A long-term climatology for the urban site U1 can be found in Christen and Vogt (2004). 


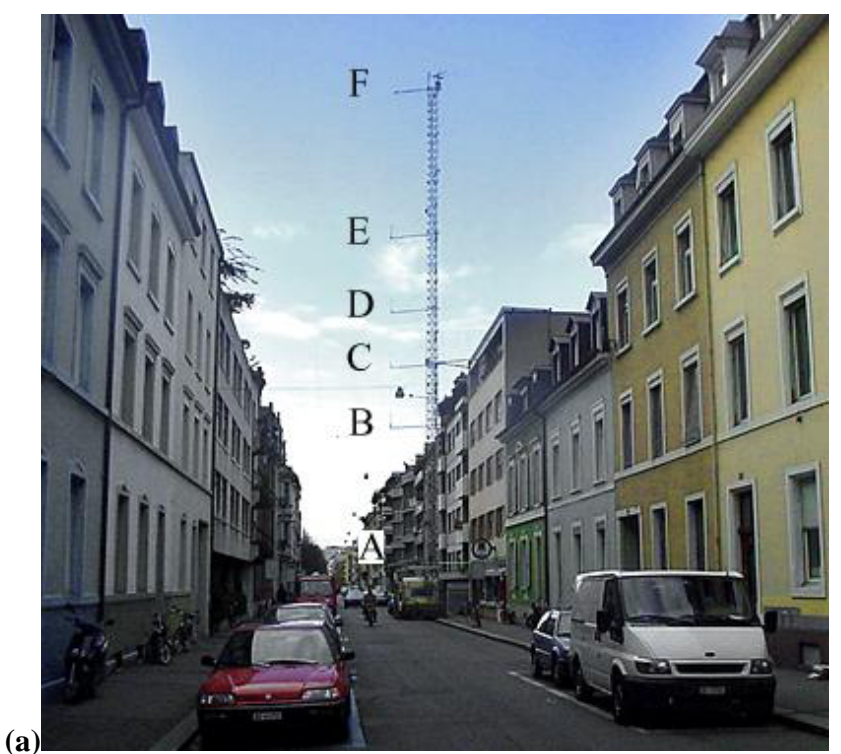

(a)

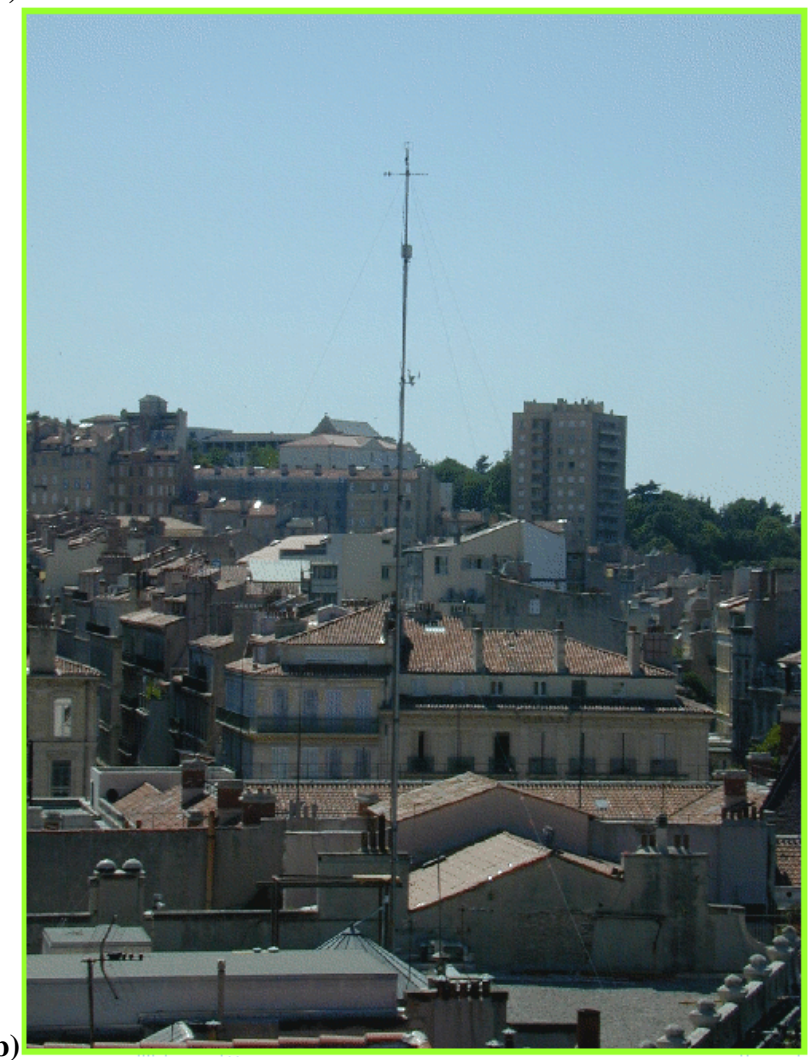

Fig. 1. The instrumentation tower at Basel-Sperrstrasse (U1) (a) and at the down-town core of Marseilles (CAA) (b). Labels refer to the instrumentation according to Table 1.

\section{Model description}

\subsection{Mesoscale model}

The three-dimensional Topographic Vorticity-mode Mesoscale (TVM) numerical model solves the atmospheric dynamic equations in vorticity mode and uses non hydrostatic, Boussinesq, and anelastic approximations (Schayes et al., 1996; Thunis and Clappier, 2000). A constant flux surface boundary layer based on the MOST formulation makes the connection with the ground surface. Surface temperature and moisture values are computed using surface energy and moisture balance equations with a modified force restore model of Deardorff (Schayes et al., 1996) forced by the solar radiation. The turbulence scheme is 1.5-order closure following the formulation of Therry and Lacarrère (1983). For rural vegetated surfaces, the latent heat flux $\mathrm{Q}_{E}$ is obtained by the Pennmann-Monteith formulation (Schayes et al., 1996).

\subsection{The urban module}

The principle of the urban surface exchange parameterization of Martilli et al. (2002), is that extra terms are added to the momentum, heat, and turbulent kinetic energy equations separately. These terms are taken into account in proportion to the area of the surface fraction of three urban surface types: street, wall, and roof. So, no moisture flux is allowed in the urban canyon. However, in the literature a lot of numerical simulations and field measurements indicate that increasing vegetation cover can be effective in reducing the surface and air temperature near the ground (Taha, 1997). In Tokyo for example, vegetated zones in summer are on the average $1.6^{\circ} \mathrm{C}$ cooler that non-vegetated zones spot (Tatsou Oka, 1980). Also, Gao (1993) found that vegetation can decrease maximum air temperature in street by $2^{\circ} \mathrm{C}$. Eliasson (1996) found that the air temperature difference observed between the large park and the city centre is of the same order as the average urban-rural air temperature difference.

In order to take into account the vegetation effect on urban canopy, we divide the urban grid cell into an non-urban fraction (vegetated fraction $\lambda_{V}$ ) and an urban fraction $1-\lambda_{V}$, and then further subdivide the urban canopy fraction into street, wall, and roof according to Martilli's scheme (see Fig. 2). This new urban canopy grid cell implies:

1. All the additional Martilli's terms for momentum, heat, and turbulent kinetic energy equations are multiplied by $1-\lambda_{V}$.

2. A new surface energy balance is calculated for the vegetated fraction surface, this new surface is considered as a rural surface. Then, the surface fluxes are calculated in proportion to the area of every urban surface types.

3. If $\lambda_{V}=0 \%$, we consider the cell as entirely urban, $\lambda_{V}=100 \%$ will turn off the urban module and consider 


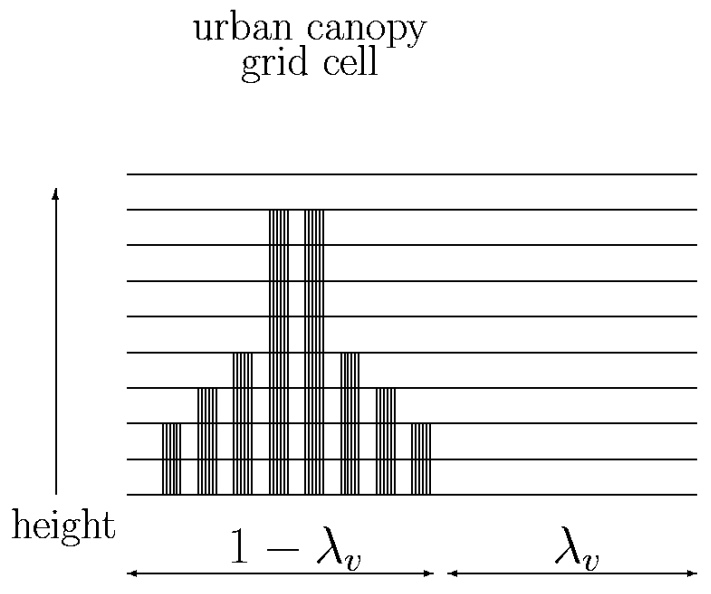

Fig. 2. Illustration of how each urban grid cell is divided up into urban and non urban fractions. The urban fraction is further subdivided into street, roof, and wall fractions.

Basel (U1)
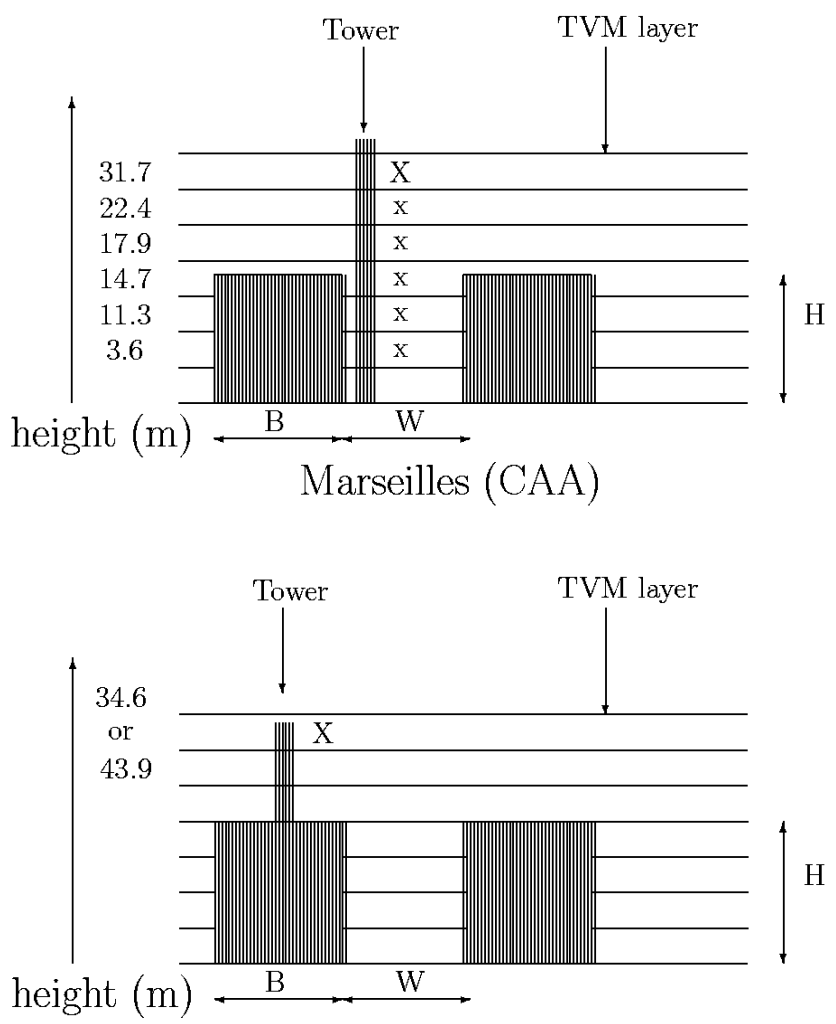

Fig. 3. Configuration of the 1-D model, with forcing from the top $(\mathrm{X})$, and calculation down to the ground in the street canyon (x), and schematic representation of the city (street and buildings) in the urban module with height of the buildings $\mathrm{H}$, width of the buildings $\mathrm{B}$, and width of the street $\mathrm{W}$. (a)

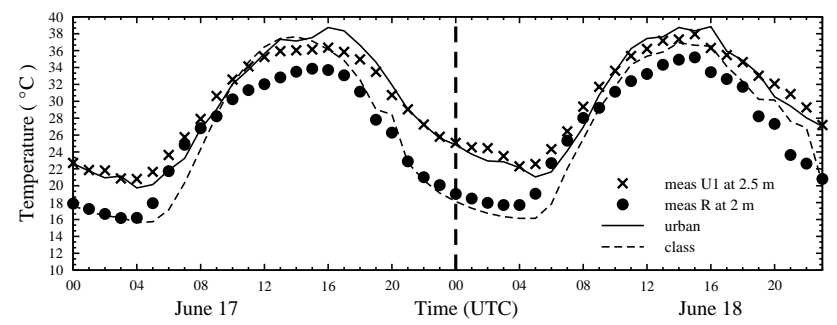

(b) June 17 at 03 UTC

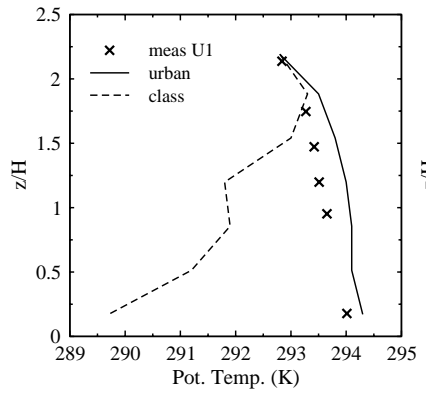

(c) June 18 at 12 UTC

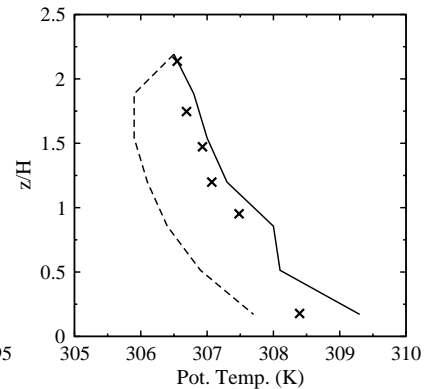

Fig. 4. (a) The time variation, from 17 June to 18 June, of the observed temperature, inside the street canyon at $2.5 \mathrm{~m}$ for $\mathrm{U} 1$ and at $2 \mathrm{~m}$ for the rural reference station $\mathrm{R}$ (Village Neuf), and computed with the urban and the classical simulation. (b) and (c): the vertical potential temperature profile in the street canyon, for 17 June at 03:00 UTC (left) and 18 June at 12:00 UTC (right), observed and computed with the urban and the classical simulation.

the cell as a rural area, percentage between 0 and $100 \%$ will perform both rural and urban calculations and weight the fluxes.

\section{The 1-D model configuration}

In this study, TVM is run on a vertical column using measurements recorded at $31.7 \mathrm{~m}$ and 37.9 or $43.9 \mathrm{~m}$, respectively, for the two towers U1 and CAA, as forcing. The model calculates the meteorological variables from these levels down to the ground for each tower separately (Fig. 3). Forcing is applied to wind, temperature, humidity, turbulent kinetic energy, and downward global short- and long-wave radiation. The period of the simulations extends from 16 June to 30 June 2002 ( 15 days) for U1 and from 18 June to 30 June 2001 (13 days) for CAA. As the model is run in a 1-D column, no horizontal advection is considered. The vertical resolution is set to $5 \mathrm{~m}$.

For each tower, two simulations were performed: the first simulation, denoted "urban", uses the urban version of TVM, the second simulation, called "class", represents the classical approach used in TVM to account for urban surface using the MOST formulation (city characterized only by a change in roughness length and the surface conditions). 
Table 3. Input parameters for the classical simulation and for the vegetated fraction of the urban grid cell (the same for the two urban sites). $\varepsilon$ the emissivity of the surface, $\alpha$ the albedo, $R_{\text {sur }}$ the resistivity to evaporation, Cap the heat capacity, $\mathrm{Z}_{0}$ the roughness length, $t_{g}$ the surface temperature, and $t_{2}$ the soil temperature.

\begin{tabular}{llllllll}
\hline & $\varepsilon$ & $\alpha$ & $R_{\text {sur }}\left(\mathrm{s} \mathrm{m}^{-1}\right)$ & $\mathrm{Cap}\left(\mathrm{J} \mathrm{m}^{-2} \mathrm{~K}^{-1}\right)$ & $\mathrm{Z}_{0}(\mathrm{~m})$ & $\mathrm{t}_{g}\left({ }^{\circ} \mathrm{C}\right)$ & $\mathrm{t}_{2}\left({ }^{\circ} \mathrm{C}\right)$ \\
\hline Classical & 0.95 & 0.16 & 300 & $5.00 \mathrm{E}+04$ & 1.0 & 20 & 20 \\
Vegetated & 0.98 & 0.20 & 50 & $3.40 \mathrm{E}+05$ & 0.1 & 20 & 20 \\
\hline
\end{tabular}

Table 4. Morphology of the two urban sites. $\mathrm{K}_{S}$ the thermal conductivity and $\mathrm{C}_{S}$ the specific heat. Data are obtained from (Martilli et al., 2002) for U1 and from (Lemonsu et al., 2004) for CAA. The thermal conductivity and the specific heat are the same for the two urban sites.

\begin{tabular}{|c|c|c|c|c|c|c|c|c|c|c|c|c|}
\hline \multicolumn{5}{|c|}{ size $(\mathrm{m})$} & \multicolumn{3}{|l|}{$\varepsilon$} & \multicolumn{3}{|l|}{$\alpha$} & \multicolumn{2}{|c|}{$\mathrm{Z}_{0}(\mathrm{~m})$} \\
\hline Site & wall & roof & road & wall & roof & road & wall & roof & road & wall & roof & road \\
\hline U1 & 14.6 & 15 & 11.23 & 0.9 & 0.9 & 0.94 & 0.14 & 0.14 & 0.08 & - & 0.01 & 0.01 \\
\hline CAA & 15.6 & 12.6 & 9.57 & 0.9 & 0.9 & 0.94 & 0.20 & 0.22 & 0.08 & - & 0.15 & 0.05 \\
\hline
\end{tabular}

\begin{tabular}{lll}
\hline & $\mathrm{K}_{S}\left(\mathrm{~m}^{2} \mathrm{~s}^{-1}\right)$ & $\mathrm{C}_{S}\left(\mathrm{~J} \mathrm{~m}^{-3} \mathrm{~K}^{-1}\right)$ \\
\hline Wall & $6.70 \mathrm{E}-07$ & $1.40 \mathrm{E}+06$ \\
Roof & $6.70 \mathrm{E}-07$ & $1.40 \mathrm{E}+06$ \\
Road & $2.80 \mathrm{E}-07$ & $1.80 \mathrm{E}+06$
\end{tabular}

Table 5. Performance statistics for surface energy balance fluxes at U1. Obs and Urb refer to the mean value for the period of simulation. Bias=Urb-Obs, RMS error is the root-mean-square error $\left(\mathrm{W} \mathrm{m}^{-2}\right)$.

\begin{tabular}{llcccc}
\hline \multirow{5}{*}{ Total period } & & $\mathrm{Q}^{*}$ & $\mathrm{Q}_{H}$ & $\Delta \mathrm{Q}_{S}$ & $\mathrm{Q}_{E}$ \\
& Obs & 180 & 126 & 6 & 43 \\
& Urb & 179 & 124 & 25 & 20 \\
& Bias & -1 & -2 & 19 & -23 \\
& RMS error & 11 & 30 & 36 & 32 \\
Naytime & Obs & 396 & 213 & 100 & 66 \\
& Urb & 393 & 223 & 114 & 39 \\
& Bias & -3 & 10 & 14 & -27 \\
& RMS error & 13 & 36 & 38 & 40 \\
& Obs & -81 & 22 & -104 & 14 \\
& Urb & -82 & 7 & -86 & 0 \\
& Bias & -1 & -15 & 18 & -14 \\
& RMS error & 7 & 20 & 32 & 18 \\
\hline \multirow{5}{*}{ Nightime }
\end{tabular}

In Table 3, we summarize the input parameters used for the classical simulation and for the vegetated fraction of the urban grid cell and in Table 4, we present the input urban parameters used for the two urban sites U1 and CAA.

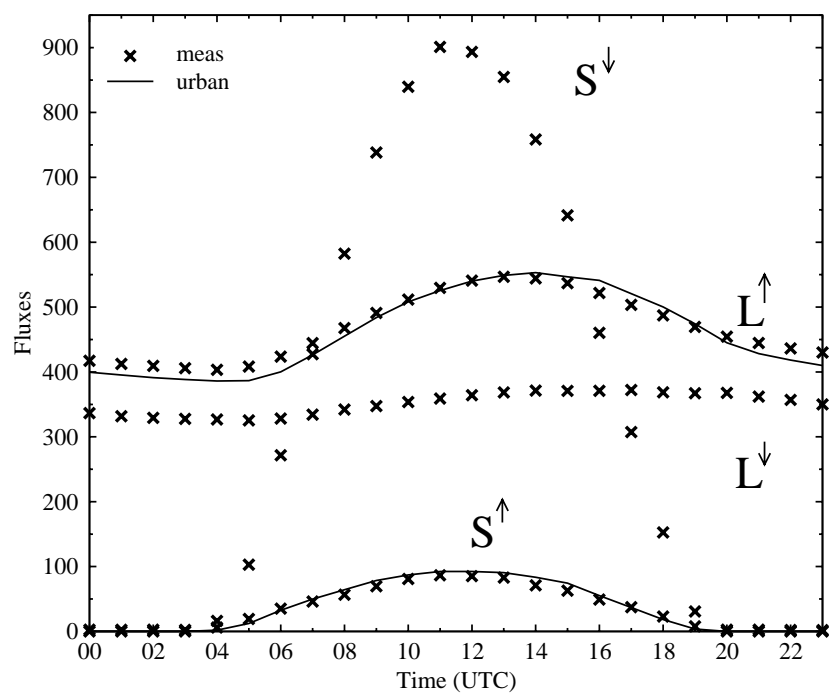

Fig. 5. Comparison between observed and simulated radiative fluxes $\left(\mathrm{W} \mathrm{m}^{-2}\right)$. Five clear sky days are chosen, 17, 18, 23, 26, and 30 June over which the modeled and observed radiative fluxes are then averaged. The black asterisks represent the observed incoming and outgoing solar $(\mathrm{S} \downarrow$ and $\mathrm{S} \uparrow$ ) and longwave ( $\mathrm{L} \uparrow$ and $\mathrm{L} \downarrow$ ) radiation recorded at the top of the tower. The black lines represent the simulated outgoing solar and longwave radiation averaged according to surface fractions. 
Latent heat flux

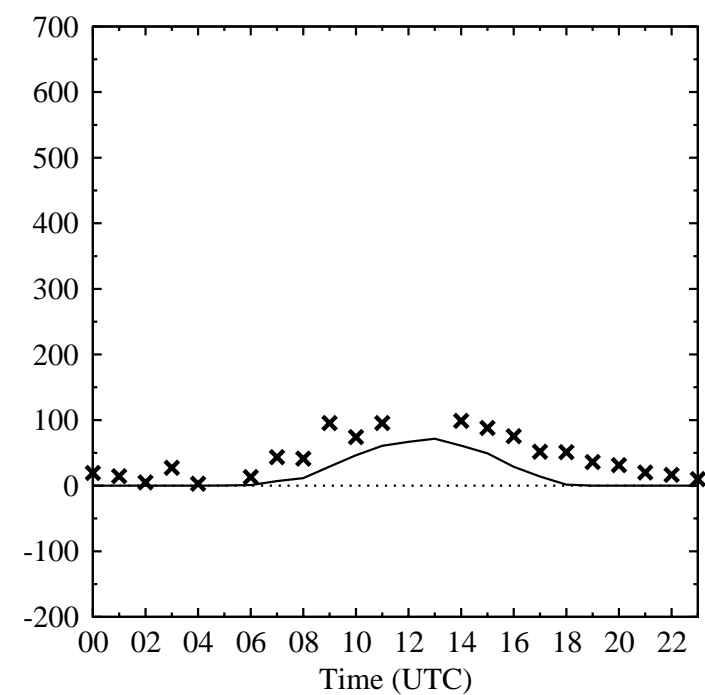

Sensible heat flux

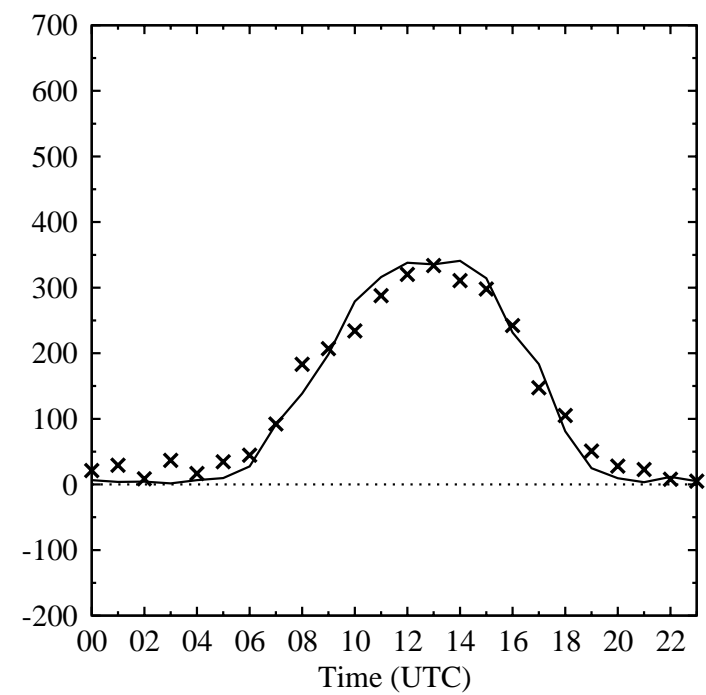

Net radiation

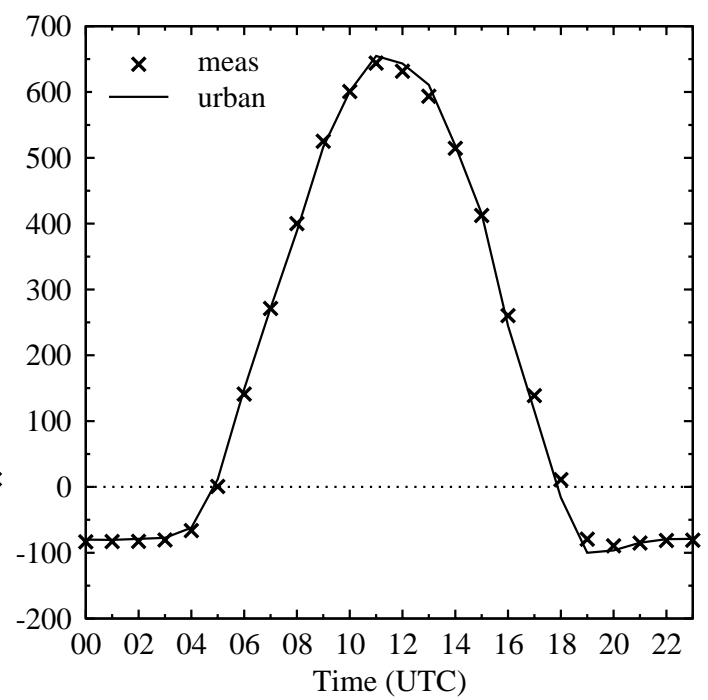

Storage heat flux

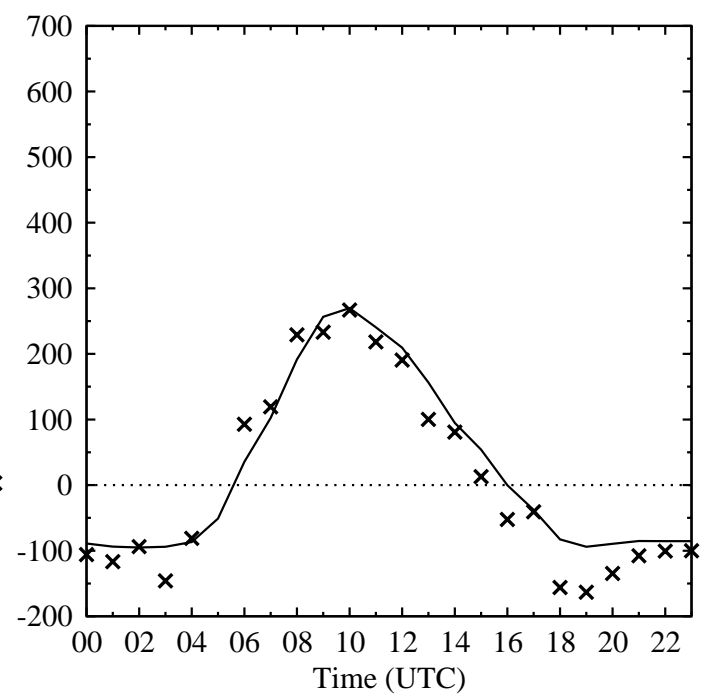

Fig. 6. Comparison between observed and simulated surface energy balance. Five clear sky days are chosen, 17, 18, 23, 26, and 30 June over which the modeled and observed surface energy fluxes are then averaged. The black asterisks are the observed fluxes (W $\mathrm{m}^{-2}$ ) at the top of the tower (the heat storage flux $\Delta \mathrm{Q}_{S}$ was determined as the residual term). The black lines are the simulated fluxes computed with the urban simulation. The simulated fluxes are averaged according to surface fractions (roads, walls, roofs, and vegetated areas).

\section{Results and discussions}

\subsection{Basel, Switzerland}

\subsubsection{Canyon air temperature}

Figure 4a shows the time variation, from 17 June to 18 June ( 2 clear sky days), of the observed temperature, inside the street canyon at $2.5 \mathrm{~m}$ for $\mathrm{U} 1$ and at $2 \mathrm{~m}$ for the rural reference station R (Village Neuf), and computed with the urban simulation and the classical simulation. Good correlation is found between the urban simulation and the observations measured inside the urban canyon at U1. The urban simulation takes into account radiation trapping effects in the street canyon. Cooling during nighttime is therefore less important than with the classical simulation. As a result, the classical simulation underestimates the daily minimum by 3 to $5^{\circ} \mathrm{C}$. The same result is found in a recent study by Roulet et al. (2005) in which they validate Martilli's urban module in 1-D column over U1 from 25 June to 27 June 2002. Taking into account, differential heating/cooling of buildings surfaces, radiation trapping effects in street canyon and heat storage in buildings allow the urban simulation to reproduce 


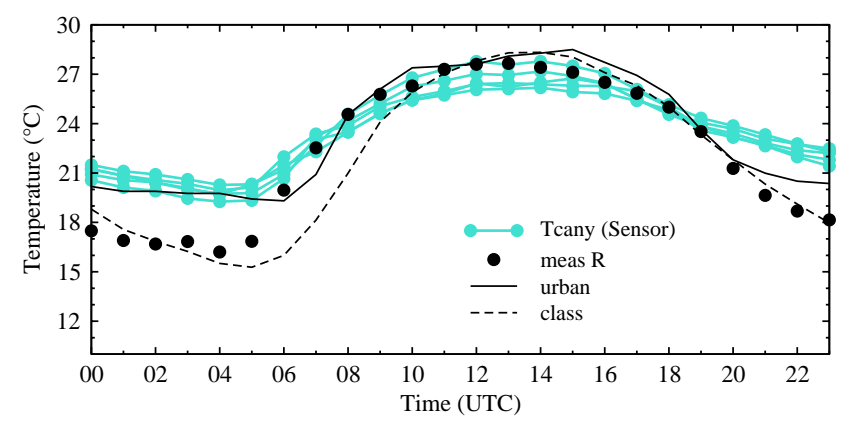

Fig. 7. The comparison between simulated canyon air temperature and observed, at five in-canyon stations in Marseilles city center and at the reference rural station R (zone 11, Lemonsu et al., 2004), averaged for 13 days, from 18 June to 30 June 2001. Two simulations were performed: the first simulation, denoted "urban", uses the urban version of TVM, the second simulation, called "class", represents the classical approach used in TVM to account for urban surface.

correctly the urban energy budget. For the urban simulation the warming up begins later and is less important than for the rural temperature. The incident energy is used by the surfaces to heat the atmosphere, for heat storage, and as an evaporation flux. Since the heat storage in artificial materials is dominant in the morning in urban areas, the atmospheric warming is delayed and limited. In the same way, urban cooling is reduced because of the heat release by the surfaces to the atmosphere (Lemonsu and Masson, 2002).

The vertical profile of potential temperature at nighttime and at the time of the daily maximum shows similar behaviour to the observations, for both days. Therefore, in Figs. $4 \mathrm{~b}$ and $\mathrm{c}$, we show only the observed and simulated profile of potential temperature for 17 June at 03:00 UTC and 18 June at 12:00 UTC. The nocturnal urban canopy computed with the urban simulation is radically different from the classical one, the urban profile shows a slightly unstable layer, while the classical profile presents a stable layer close to the ground. In fact, the urban module of Martilli calculates heat fluxes from the street as well as from the walls. Heat sources are then distributed along the vertical up to roof height, whereas the classical parameterization has a unique source at the ground. Vertical profile of potential temperature at the time of the daily maximum (Fig. 4c) shows a pronounced gradient immediately above roof level and small gradients beneath and above (Roulet et al., 2005). The urban simulation is able to reproduce this shape, but overestimates the temperature at the surface by $1^{\circ} \mathrm{C}$.

\subsubsection{Surface radiation budget}

The simulated total surface fluxes $\phi_{\mathrm{T}}$ are calculated in TVM as:

$\phi_{\mathrm{T}}=\frac{\lambda_{v}}{100} \phi_{\mathrm{rur}}+\left(1-\frac{\lambda_{v}}{100}\right) \phi_{\mathrm{urb}}$
Where $\phi_{\text {rur }}$ is the surface fluxes coming from the vegetated part, and $\phi_{\text {urb }}$ is the urban contribution, which is calculated as:

$\phi_{\text {urb }}=\phi_{\text {floor }}+\frac{1}{W} \sum \Delta z_{i}\left(\phi_{i}^{\text {West }}+\phi_{i}^{\text {East }}\right)$

with $\phi_{\text {floor }}$ the sum between the surface fluxes calculated from the street and the roof, $W$ width of the street canyon, $\Delta \mathrm{z}_{i}$ the vertical grid spacing in the urban grid, $\phi^{\text {West }}$ and $\phi^{\text {East }}$ the surface fluxes calculated from the West and East wall respectively (Martilli et al., 2002). The sum is computed between the lowest and the highest urban grid level. Five clear sky days are chosen $(17,18,23,26$, and 30 June) over which the modeled and observed surface fluxes are then averaged. The incoming and outgoing global short- and longwave radiation fluxes were recorded near the top of the tower. Both incoming long- $\mathrm{L} \downarrow$ and shortwave $\mathrm{S} \downarrow$ radiation are used to force the surface scheme. The fraction of incident radiation absorbed by built and natural surfaces is computed by TVM (separately for roads, walls, roofs, and vegetated areas). Both short- and longwave upward-simulated radiation, weighted according to natural and built surface fractions, are compared with the observations in Fig. 5.

The upward shortwave radiation is very well reproduced by the urban module of Martilli, and the mean daily albedo is in good agreement with the measured 0.10 (Christen and Vogt, 2004). The upward longwave radiation is slightly underestimated by the urban module during the night. The bias of upward longwave radiation is apparently due to a higher urban radiation surface temperature and/or a different emissivity.

\subsubsection{Surfaces energy fluxes}

The model is evaluated using the measured hourly energy fluxes: net radiation, sensible heat flux, and latent heat flux. Figure 6 gives the ensemble mean results and Table 5 the summary statistics.

The daytime/nighttime $\mathrm{Q}^{*}$ is very well reproduced (Table 5). During the day, the observed sensible heat flux $\mathrm{Q}_{H}$ is characteristically around $50 \%$ of $\mathrm{Q}^{*}$. In fact, given the small vegetation cover in the city center which limits the evapotranspiration process, one is interested on energy sharing between the two sensible heat fluxes: conduction into the underlying buildings and ground $\Delta \mathrm{Q}_{S}$ and convection to the air $\mathrm{Q}_{H}$. At night, the average hourly observed sensible flux is positive. Consequently, during nighttime, more energy is given back to the surface in the city center. This means that the feed-back of energy to the surface during nighttime is able to counterbalance and even overcome the radiation loss. The urban module reproduces very well the observations. During the night, the model succeeds in producing a positive sensible heat flux. The observed heat storage flux $\Delta \mathrm{Q}_{S}$ increases more rapidly during the morning than the sensible heat flux and peaks before (Fig. 6). Whereas, the sensible heat flux almost reaches its maximum in the afternoon. 

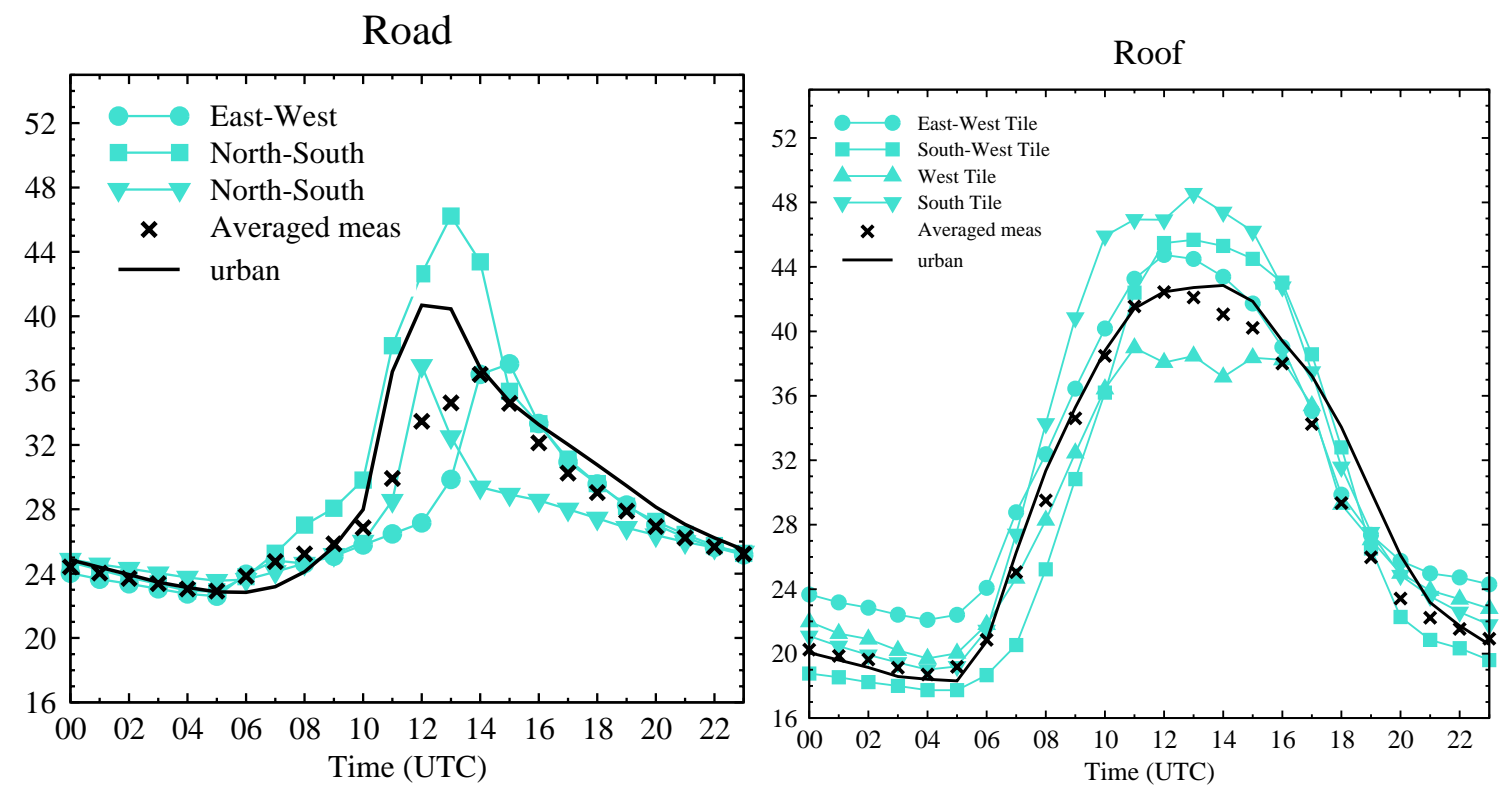

\section{Wall}

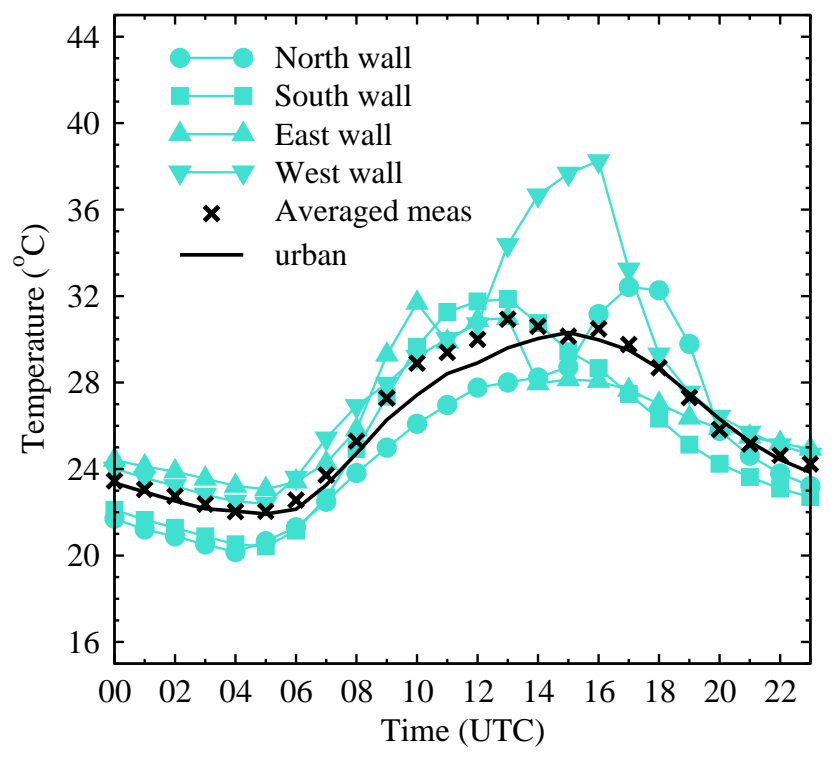

Fig. 8. Comparison between observed and simulated wall, roof, and road surface temperature averaged for 13 days, from 18 June to 30 June 2001. The gray lines represent all of the measurements, while the asterisks present the mean observed surface temperature weighted by street orientation. The black lines represent the surface temperature computed by TVM.

During the afternoon, the heat storage flux gets negative and releases energy to the surface one or two hours before the radiation balance changes sign. The huge daytime $\Delta \mathrm{Q}_{S}$ into buildings is counterbalanced by an extremely high nocturnal release of $\Delta \mathrm{Q}_{S}\left(\Delta \mathrm{Q}_{S} / \mathrm{Q}^{*}=1.3\right)$ which can be even higher in magnitude than the radiative loss. This imbalance maintains an average upward-directed $\mathrm{Q}_{H}$ of $22 \mathrm{~W} \mathrm{~m}^{-2}$. The model produces a nighttime $\Delta \mathrm{Q}_{S} / \mathrm{Q}^{*}$ ratio of 1 . Therefore, the modeled $\mathrm{Q}_{H}$ reaches only $7 \mathrm{~W} \mathrm{~m}^{-2}$, on average. Also, the urban module seems to underestimate the daily maximum latent heat flux due to the omission of the anthropogenic heat flux in the urban model simulations. Christen and Vogt (2004) estimate an anthropogenic heat flux of approximately $+20 \mathrm{~W} \mathrm{~m}^{-2}$ at $\mathrm{U} 1$.

Thus in summary, TVM is able to reproduce correctly most of the behavior of the fluxes typical of the city center of Basel, including the large heat uptake by the urban fabric, and the positive $\mathrm{Q}_{H}$ at night. 


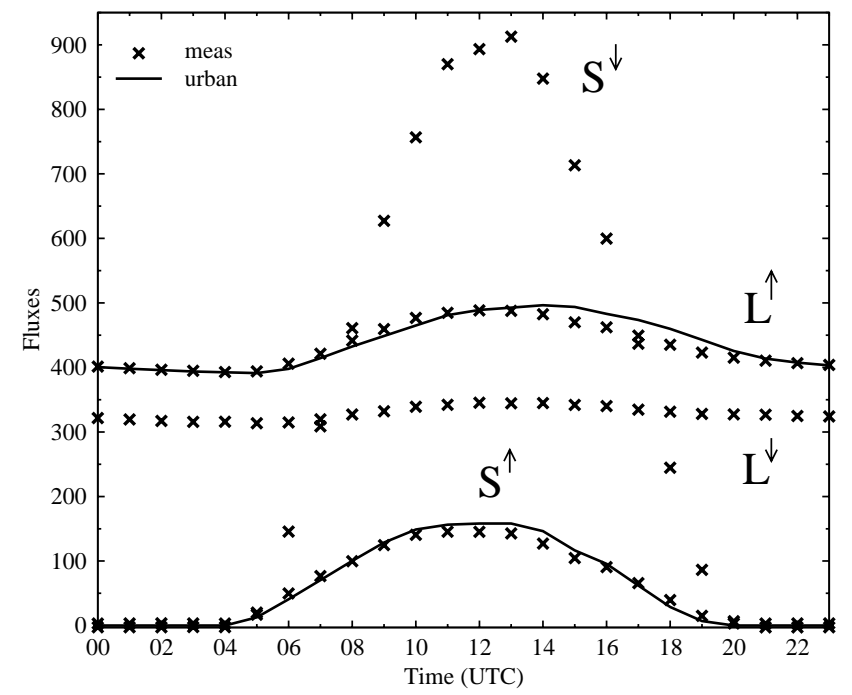

Fig. 9. Comparison between observed and simulated radiative fluxes $\left(\mathrm{W} \mathrm{m}^{-2}\right)$ averaged for 13 days, from 18 June to 30 June 2001. The black asterisks represent the observed incoming and outgoing solar ( $\mathrm{S} \downarrow$ and $\mathrm{S} \uparrow$ ) and longwave ( $\mathrm{L} \uparrow$ and $\mathrm{L} \downarrow$ ) radiation recorded at the top of the tower. The black lines represent the simulated outgoing solar and longwave radiation averaged according to surface fractions.

\subsection{Marseilles, France}

\subsubsection{Canyon air temperature}

Figure 7 shows the comparison between simulated canyon air temperature and observed, at five in-canyon stations in Marseilles city center and at the reference station R (zone 11) (Lemonsu et al., 2004), averaged for 13 days (from 18 June to 30 June 2001).

The observed canyon air temperature varies slightly from one station to another, influenced by the distance to the coastline, vegetation close to the sensor, the aspect ratio of the street, and the exact nature of buildings. The daily evolution of the temperature in the street canyon is fairly well represented by the urban boundary layer scheme. At night, the classical simulation is not able to represent the heat storage near the ground, whereas the urban simulation indicates a temperature very close to the measurements $\left(4-5^{\circ} \mathrm{C}\right.$ higher than the classical simulation at 04:00 UTC), and is thus able to represent the nocturnal Heat Island Effect over urban area.

\subsubsection{Surface temperature}

In the urban module of Martilli (Martilli et al., 2002), the surface temperature for wall, roof, and road are resolved by integration across two street orientations $\left(84^{\circ}\right.$ and $\left.174^{\circ}\right)$ presented in Table 1. One mean surface temperature is then calculated for each surface types. To compare these average surface temperatures calculated by TVM with observations, the
Table 6. Performance statistics for road, wall, and roof surface temperature at $\mathrm{CAA}\left({ }^{\circ} \mathrm{C}\right)$.

\begin{tabular}{ccc}
\hline & Bias (Urb-Obs) & RMS error \\
\hline $\mathrm{T}_{\text {road }}$ & 1.2 & 2.5 \\
$\mathrm{~T}_{\text {wall }}$ & -0.3 & 0.6 \\
$\mathrm{~T}_{\text {roof }}$ & 0.9 & 1.7 \\
\hline
\end{tabular}

average observed surface temperatures are calculated over all existed street orientations, because in the Escompte-UBL campaign, sensors were installed in different locations in the area around the tower (Lemonsu et al., 2004). The results of the comparison of mean observed and modelled surface temperature are presented in Fig. 8. Table 6 gives the summary statistics.

The general form of the diurnal evolution of roof and wall are correctly reproduced by TVM. However, for road temperature, the comparison shows a good agreement at night but an overestimation of the maximum road temperature during the day by $5^{\circ} \mathrm{C}$. This bias for the road temperature has been simulated also by Lemonsu et al. (2004) with the Masson (2000) Town Energy Balance (TEB) scheme validated over the Marseilles city center. According to Lemonsu et al. (2004), this bias may be due to fact that:

1. The observations were conducted in narrow streets with aspect ratios of about 2, whereas for the model simulation an aspect ratio of 1.6 is used (Table 1).

2. Only three road surface temperature sites were available. However, more measurements are available for wall and roof.

However, the comparison between the statistics performances of Martilli's and TEB schemes shows that the bias of the road temperature is clearly lower for Martilli's scheme with a value of $1.2^{\circ} \mathrm{C}$ against $2.2^{\circ} \mathrm{C}$ for TEB and the rootmean-square error (rmse) is smaller for all surface temperatures.

\subsubsection{Radiative fluxes}

The upward shortwave radiation is very well reproduced by the urban module (Fig. 9), and the mean daily albedo is in good agreement with measurement (about 0.14 Lemonsu et al., 2004). The upward longwave radiation is slightly overestimated by the urban simulation in the afternoon. Given the geometric parameter values used for Marseilles, most upward radiation comes from the roofs. The bias of upward longwave radiation is apparently due to a too high emission from the roofs, where the surface temperature is overestimated by the urban simulation in the afternoon. 
Latent heat flux

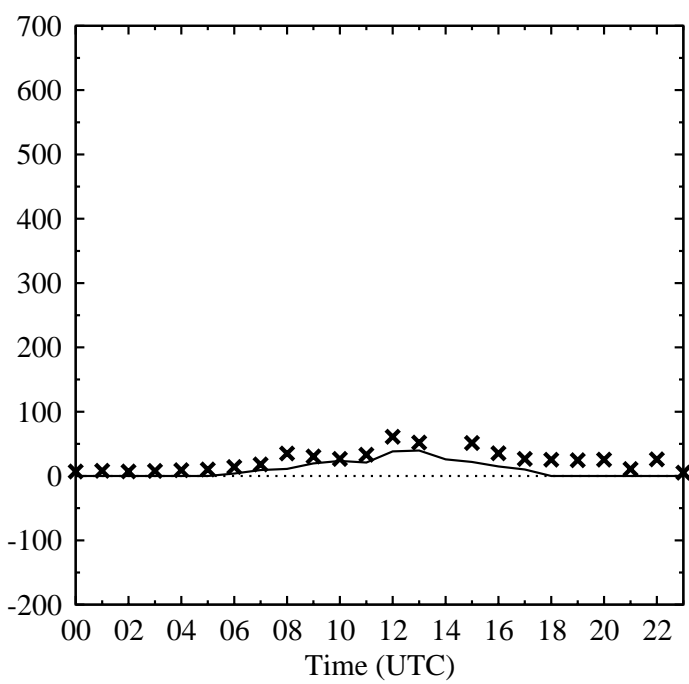

Sensible heat flux

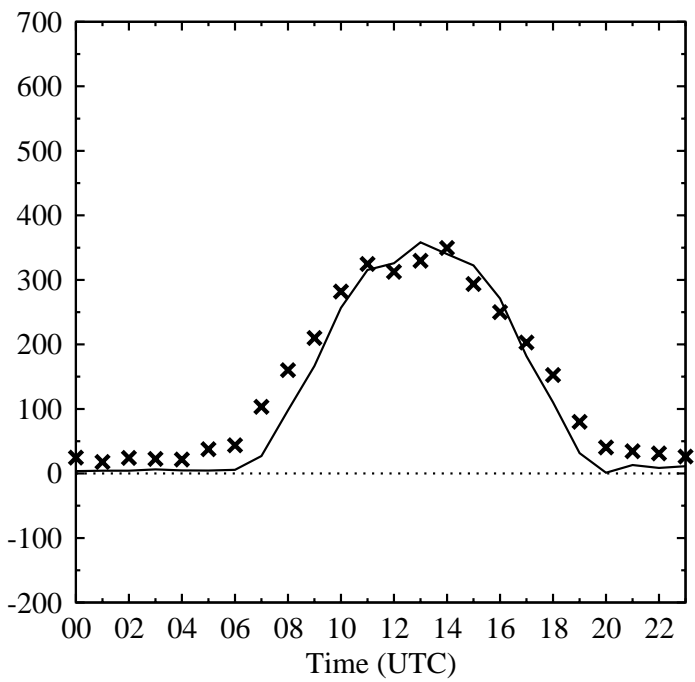

Net radiation

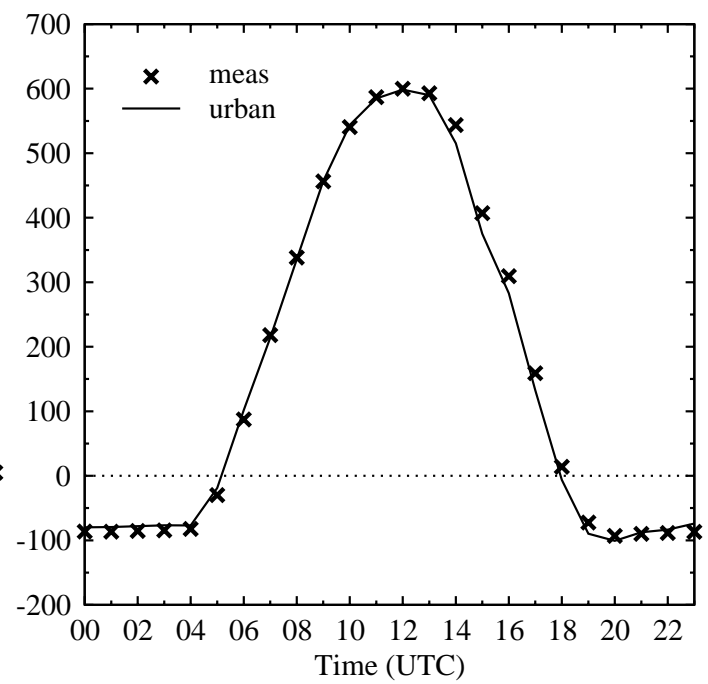

Storage heat flux

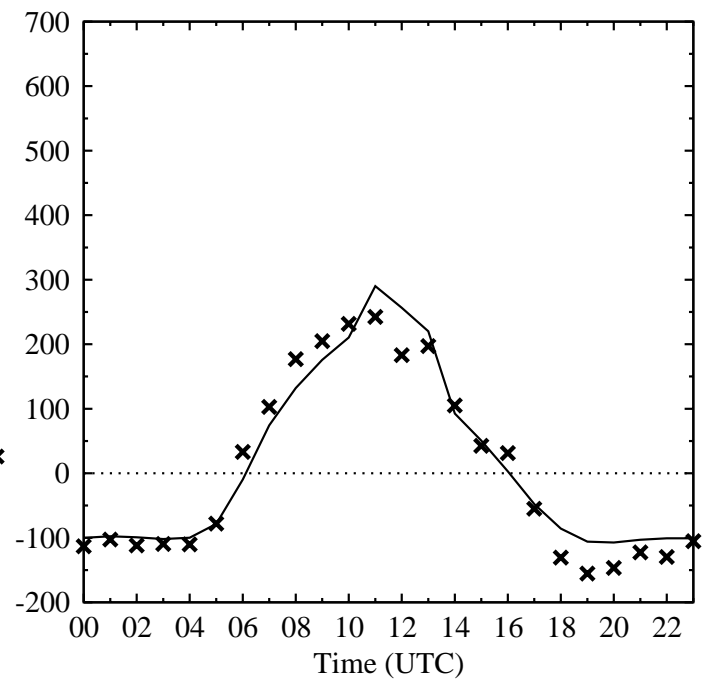

Fig. 10. Comparison between observed and simulated surface energy fluxes ( $\mathrm{W} \mathrm{m}^{-2}$ ) averaged for 13 days, from $18 \mathrm{June}$ to $30 \mathrm{June} 2001$. The black asterisks are the observed fluxes at the top of the tower (the heat storage flux $\Delta \mathrm{Q}_{S}$ was determined as the residual term). The black lines are the simulated fluxes computed with the urban simulation. The simulated fluxes are averaged according to surface fractions (roads, walls, roofs, and vegetated areas).

\subsubsection{Surface energy fluxes}

The flux measurements recorded at the top of the tower are compared with the averaged energy fluxes computed by TVM (Fig. 10). The bias and rmse for the overall, nighttime, and daytime periods are given in Table 7. The comparison with the statistics performances of TEB (see Table 4 in Lemonsu et al., 2004) shows that the bias and rmse are clearly lower with Martilli's scheme on the overall period for net radiation, sensible, and storage heat fluxes. The latent heat flux however, seems to be much more underestimated with Martilli's scheme.
The model correctly reproduces $\mathrm{Q}^{*}$ during the entire period. As Table 7 shows, this is true for the overall set (bias $=-4 \mathrm{~W} \mathrm{~m}^{-2}$ ) and for both day and night (biases of -10 and $3 \mathrm{~W} \mathrm{~m}^{-2}$, respectively). During the day, observed $\mathrm{Q}_{H}$ is large and is characteristically around $63 \%$ of $\mathrm{Q}^{*}$ (model $59 \%$ ). The increased $\mathrm{Q}_{H} / \mathrm{Q}^{*}$ at $\mathrm{CAA}$ is counterbalanced by reduced $\mathrm{Q}_{E} \mathrm{Q}_{E} / \mathrm{Q}^{*}=0.09$ (model 0.05). Just as it is found in the urban site $\mathrm{U} 1$, the urban simulation seems to underestimate the latent heat flux. The model succeeds in producing a positive sensible heat flux at night and the simulated heat storage flux is in good agreement with observations, with the periods of heat uptake and heat release observed also simulated by the model. 
Table 7. Performance statistics for surface energy balance fluxes at CAA. Obs and Urb refer to the mean value for the period of simulation. Bias=Urb-Obs, RMS error is the root-mean-square error $\left(\mathrm{W} \mathrm{m}^{-2}\right)$.

\begin{tabular}{llcccc}
\hline \multirow{5}{*}{ Total period } & & $\mathrm{Q}^{*}$ & $\mathrm{Q}_{H}$ & $\Delta \mathrm{Q}_{S}$ & $\mathrm{Q}_{E}$ \\
\cline { 2 - 3 } Daytime & Obs & 165 & 140 & 3 & 25 \\
& Urb & 161 & 125 & 11 & 10 \\
& Bias & -4 & -15 & 8 & -15 \\
& RMS error & 14 & 33 & 32 & 17 \\
& Obs & 373 & 232 & 105 & 35 \\
& Urb & 363 & 225 & 106 & 18 \\
& Bias & -10 & -7 & 1 & -17 \\
& RMS error & 17 & 38 & 39 & 19 \\
& Obs & -80 & 33 & -117 & 13 \\
& Urb & -77 & 8 & -100 & 0 \\
& Bias & 3 & -25 & 17 & -13 \\
& RMS error & 10 & 27 & 23 & 15 \\
\hline
\end{tabular}

\section{Conclusion and perspectives}

A detailed urban surface exchange parameterization, implemented in a mesoscale model, has been tested and compared to simulation using a classical parameterization on the one hand, and with measurements on the other hand. In the urban simulation the parameters characterizing the city are the buildings size and the street canyon width. This is different from the classical approach, which characterizes the city only by a high roughness length and a modification in the surface properties. Evaluation of the urban module of Martilli using field observations from two sparsely vegetated urban areas, with very different urban parameters and synoptic forcing, suggests that overall the urban module performs well. The results show that the urban parameterization scheme is able to represents correctly most of the behavior of the fluxes typical of the city center of Basel and Marseilles, including the large heat uptake by the urban fabric and the positive sensible heat flux at night. For Marseilles city center, characterized by the presence of strong winds, the model correctly simulates the partitioning between the turbulent and storage heat fluxes. However, for the tow locations tested in this study the vegetation fraction in each grid cell is relatively low. Thus, what is really tested is the urban part of the scheme. In Appendix A, a new simulation is added where the urban scheme is validated, in the case of the BUBBLE experiment, for a second urban site (U2) with higher fraction of vegetation (31\%). The results suggest that the simple approach to account for the presence of vegetation in cities presented in this study seems to reproduce correctly the surface energy budget for urban areas with higher fraction of vegetation. All of these results are encouraging for future 3-D modeling with the urban version of the model. Future work will involve high-resolution 3-D simulations on the region of Basel and Marseilles.

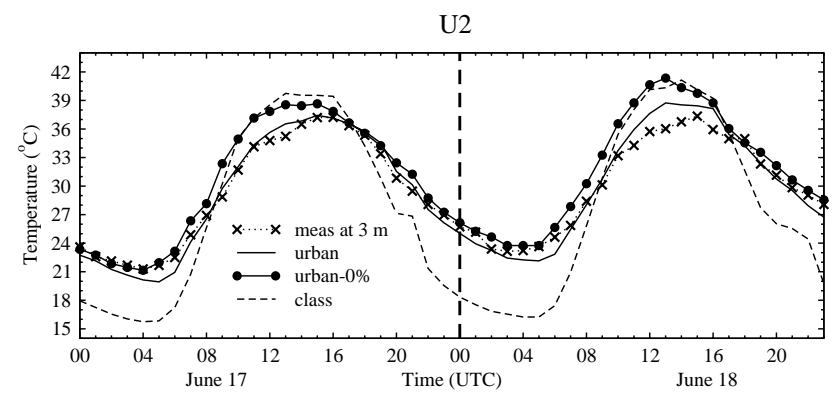

Fig. A1. The time variation, from 17 to 18 June, of the air temperature inside the street canyon $\mathrm{U} 2$ at $3 \mathrm{~m}$, observed and computed with the urban and the classical simulations. A third urban simulation, denoted urban- $0 \%$, was performed with the vegetated fraction set to $0 \%$.

\section{Appendix A}

In this study the urban parameterization scheme of Martilli et al. (2002) has been modified to incorporate the vegetated fraction in the urban grid cell. So, in order to ensure that the revisited Martilli's scheme can be applied over suburban surfaces also, a new simulation is performed where the urban module is validated, in the case of the BUBBLE experiment, for a second urban site (U2) with higher fraction of vegetation 31\% (see Christen (2005) for more details about the urban characteristics of U2).

Figure A1 presents the time variation, from 17 June to 18 June, of the air temperature inside the street canyon $\mathrm{U} 2$ at $3 \mathrm{~m}$, observed and computed with the urban and the classical simulations. A third urban simulation, denoted urban- $0 \%$, was performed with the vegetated fraction set to $0 \%$. Good correlation is found between the urban simulation and the observations. However, the urban- $0 \%$ simulation overestimates the average daily maximum temperature by $3^{\circ} \mathrm{C}$. This is mainly due to the omission of the passive cooling effect of the vegetation in daytime, which leads to a serious overestimation of the air temperature especially for $\mathrm{U} 2$ where there are tree inside the street canyon.

In Fig. A2, we present the validation of the surface energy fluxes at U2. The urban simulation is in good agreement with the observations and contrarily to what is found for $\mathrm{U} 1$, the latent heat flux is correctly reproduced. The same result is found when validating Martilli's urban scheme for a suburban area with higher fraction of vegetation (described in Hamdi, 2005). Thus, the simple approach to account for the presence of vegetation in cities presented in this study seems to reproduce correctly the surface energy budget for urban areas with higher fraction of vegetation. 
Latent heat flux



Sensible heat flux

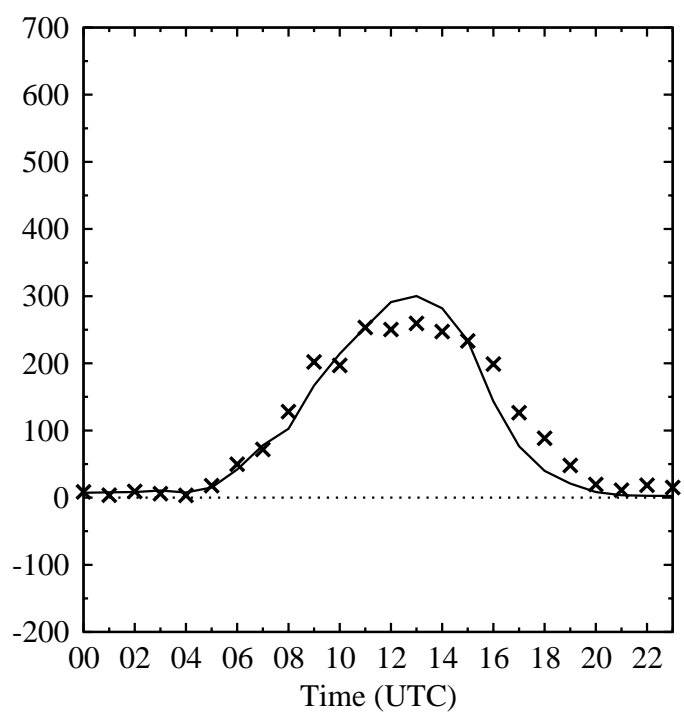

Net radiation

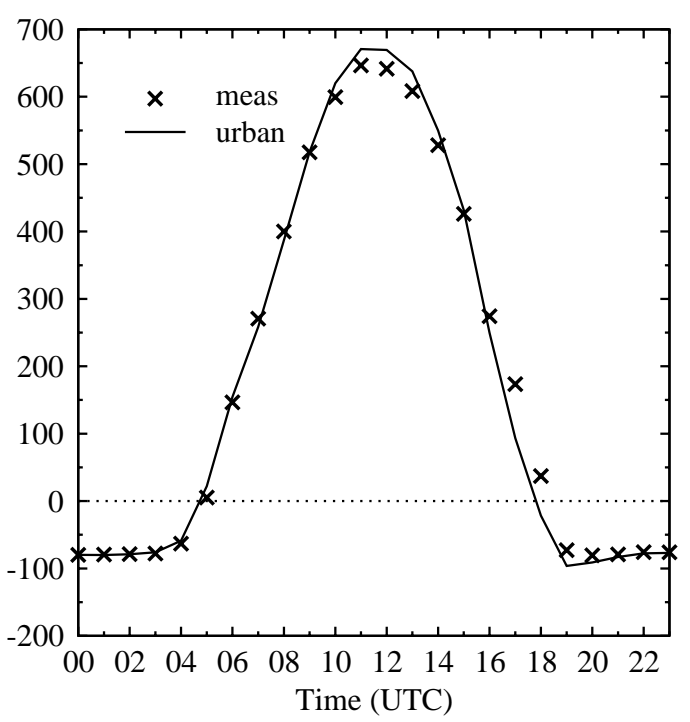

Storage heat flux

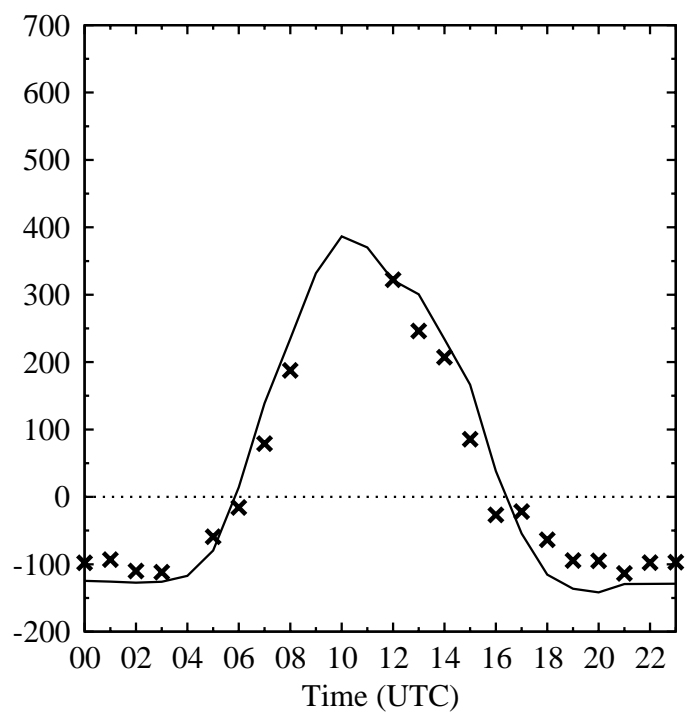

Fig. A2. Comparison between observed and simulated surface energy balance. Five clear sky days are chosen, 17, 18, 23, 26, and 30 June over which the modeled and observed surface energy fluxes are then averaged. The black asterisks are the observed fluxes $\left(\mathrm{W} \mathrm{m}^{-2}\right)$ at the top of the tower at $\mathrm{U} 2$ (the heat storage flux $\Delta \mathrm{Q}_{S}$ was determined as the residual term). The black lines are the simulated fluxes computed with the urban simulation. The simulated fluxes are averaged according to surface fractions (roads, walls, roofs, and vegetated areas).

Acknowledgements. Thanks to A. Martilli for providing us the code of his urban boundary layer scheme. Martilli's urban boundary layer scheme is obtained in the frame of the EU-FUMAPEX project. The authors are very grateful to A. Christen for providing the BUBBLE database, J.-L. Boichard and P. Durand for providing ESCOMPTE-UBL database. Many thanks go to A. Clappier, Y.-A. Roulet, and C. Muller who provided assistance. We thank M. Rotach and the anonymous reviewer for helpful suggestions.

Edited by: S. Galmarini

\section{References}

Bornstein, R. D.: Mean diurnal circulation and Thermodynamic Evolution of Urban Boundary Layers, Modelling the Urban Boundary Layer, published by American Meteorological Society, Boston, MA, 53-94, 1987.

Brown, M. and Williams, M.: An urban canopy parameterization for mesoscale meteorological models, AMS 2nd Urban Env. Symp., Albuquerque, NM, 1998.

Brown, M.: Urban parameterizations for mesoscale meteorological models, Mesoscale Atmospheric dispersion, edited by: Boybey, 
Z., Wessex press, 2000.

Ca, V., Asaeda, T., and Ashie, Y.: Development of a numerical model for the evaluation of the urban thermal environment, J. Wind. Eng. Ind. Aerodyn., 81, 181-196, 1999.

Christen, A.: Atmospheric turbulence and surface energy exchange in urban environments, Ph.D. thesis, Univ. Basel, Switzerland, 130 pp, 2005.

Christen, A. and Vogt, R.: Energy and radiation balance of a central European city, Int. J. Climatol., 24, 1395-1421, 2004.

Eliasson, I.: Urban nocturnal temperatures, street geometry and land use, Atmos. Environ., 30, 379-392, 1996.

Gao, W.: Thermal effects of open space with a green area on urban environment, Part 1: a theoretical analysis and its application, J. Archit. Plan. Environ. Eng., AIJ, No. 448, 1993.

Hamdi, R.: Numerical study of the atmospheric boundary layer over urban areas: validation for the cities of Basel and Marseille, Ph.D. thesis, Univ. Louvain, Belgium, 242 pp, 2005.

Lemonsu, A. and Masson, V.: Simulation of a summer urban breeze over Paris, Bound. Lay. Meteorol., 104, 463-490, 2002.

Lemonsu, A., Grimmond, C. S. B., and Masson, V.: Modelling the surface energy balance of the core of an old Mediterranean city: Marseilles, J. Appl. Meteorol., 43, 312-327, 2004.

Martilli, A., Clappier, A., and Rotach, M. W.: An urban surface exchange parameterization for mesoscale models, Bound. Lay. Meteorol., 104, 261-304, 2002.

Maruyama, T.: Surface and inlet boundary conditions for the simulation of turbulent boundary layer over complex rough surface, J. Wind. Eng. Ind. Aerodyn., 81, 311-322, 1999.

Masson, V.: A physically-based scheme for the urban energy budget in atmospheric models, Bound. Lay. Meteorol., 94, 357-397, 2000.

Mestayer, P. G., Durand, P., Augustin, P., et al.: The urban boundary layer field experiment over Marseille. UBL/CLU-ESCOMPTE: Experimental set-up and first results, Bound. Lay. Meteorol., 114, 315-365, 2005.

Pigeon, G., Lemonsu, A., Durant, P., and Masson, V.: Urban surface network in Marseille: Network optimization using numerical simulations and results, Preprints, Fourth Symp. on the Urban Environment, Norfolk, VA, Am. Meteorol. Soc., 23-24, 2002.
Rotach, M. W.: Turbulence close to a rough urban surface. Part1: Reynold Stress, Bound. Lay. Meteorol., 65, 1-28, 1993.

Rotach, M. W.: Turbulence close to a rough urban surface. Part 2: Variances and gradients, Bound. Lay. Meteorol., 65, 1-28, 1993.

Rotach, M. W., Vogt, R., Bernhofer, C., Batchavarova, E., Christen, A., Feddersen, B., Gryning, S.-E., Martucci, G., Mayer, H., Mitev, V., Oke, T. R., Parlow, E., Richner, H., Roth, M., Roulet, Y. A., Ruffieux, D., Salmond, J., Schatzmann, M., and Voogt, J.: BUBBLE: a Major Effort in Urban Boundary Layer Meteorology, Theor. Appl. Climatol., 81, 231-261, 2005.

Roulet, Y.-A., Martilli, A., Rotach, M. W., and Clappier, A.: Validation of an urban surface exchange parameterization for mesoscale models - 1D case in a street canyon, J. Appl. Meteorol., 44, 1484-1498, 2005.

Schayes, G., Thunis, P., and Bornstein, R.: Topographic VorticityMode Mesoscale- $\beta$ (TVM) Model. Part1: Formulation, J. Appl. Meteorol., 35, 1815-1824, 1996.

Sievers, U.: Dreidimensionale simulation in stadtgebieten, Schriftenreihe Umweltmeteorologie Band 15 (in German), Kommission Reinhaltung der Luft im VDI und DIN, Dusseldorf, 3643, 1990.

Taha, H.: Modeling the impacts of large-scale albedo changes on ozone air quality in the south coast air basin, Atmos. Environ., 31, 1667-1676, 1997.

Taha, H.: Modifying a mesoscale meteorological model to better incorporate urban heat storage: bulk-parameterization approach, J. Appl. Meteorol., 38, 466-473, 1999.

Tatsou Oka: Thermal environment in urban areas, Report D7: 1980, Swedish Council for Building Research, Stockholm, Sweden, 1980.

Therry, G. and Lacarrère, P.: Improving the eddy kinetic energy model for planetary boundary layer description, Bound. Lay. Meteorol., 25, 63-88, 1983.

Thunis, P. and Clappier, A.: Formulation and Evaluation of a Nonhydrostatic Mesoscale Vorticity Model (TVM), Mon. Weather Rev., 128, 3236-3251, 2000.

Urano, A., Ichinose, T., and Hanaki, K.: Thermal environment simulation for 3-D replacement of urban activity, J. Wind Eng. Ind. Aerodyn., 81, 197-210, 1999. 